\title{
BIM A VIRTUÁLNÍ REALITA V PRAXI
}

\author{
Miriam MUROŇOVÁ \\ ${ }^{1}$ Ateliér Ostrava, Místecká 329/258, 72000 Ostrava - Hrabová \\ muronova@atelier-ostrava.cz \\ doi: https://doi.org/10.31490/9788024845081-113
}

\begin{abstract}
Abstrakt
Potřeba virtuální reality a metody jejího využití při projekci staveb metodou informačního modelování budov (BIM). Představení softwarových a hardwarových nástrojů nutných $\mathrm{k}$ implementaci virtuální reality. Uvedení do specifik procesů workflow přímého propojení BIM projekce $s$ VR $v$ praxi projekční kanceláře. Ukázka výstupů na vybraných stavbách v různých stupních rozpracovanosti projektové dokumentace.
\end{abstract}

\begin{abstract}
The need of virtual reality and the methods of its use in building design utilizing Building Information Modeling (BIM). Introduction to software and hardware tools which are necessary for implementation of virtual reality. Example of the specifics of workflow processes to make direct connection between BIM projection and VR in practice for design engineers. Presentation of outputs for selected buildings in various stages of development of project documentation.
\end{abstract}

Klíčová slova: BIM; VR; informační modelování budov; virtuální realita;

Keywords: BIM; VR; building information modeling; virtual reality

\section{POTŘEBA VIRTUÁLNÍ REALITY V ARCHITEKTUŘE}

Potřebujeme skutečně virtuální realitu $v$ architektuře? Je to tak, že jsme poznali novou digitální cestu a hledáme pro ni uplatnění, nebo virtuální realita vznikla prímo z potřeb architektury?

$U$ mě to byla rozhodně druhá možnost. Když se vrátíme $v$ čase do roku 2009 a podíváme se na můj první model $v$ Revitu, pochopíte, že zároveň s úžasem, že vidím, co vytvářím i v 3D náhledu, zde byla i určitá otázka. Proč se nemůžu dostat dovnitř? Proč se modelem nemůžu volně pohybovat, procházet? (video)

Ačkoli jiné vizualizační programy na to byly trochu lépe, nebylo to nikdy úplně ono. A tak vznikla ta myšlenka, sen. Najít cestu, jak se modelem volně procházet. Moci se volně procházet projektovým modelem s vnímáním požadované míry detailu. Reálná vizuální kontrola BIM díla.

Pojd'me se podívat, jak to bylo s dostupností nástrojů pro VR tehdy a dnes.

\section{SOFTWAROVÉ A HRADWAROVÉ NÁSTROJE}

$\checkmark$ roce 2009 byla vize o volném procházení ještě daleko za hranicí tehdejší komerčně dostupné techniky. Ve stejném roce teprve započal vývoj Palmer Freeman Luckey z Californie a po třech letech $v$ roce 2012 představuje prototyp brýlí, které začaly psát dějiny komerční VR tak jak ji známe dnes.

O tom, že se cesta za mým snem vyvijí kdesi daleko beze mě, jsem se dozvěděla v roce 2014 z článku z časopisu Respekt. Věděla jsem tedy, že správná chvíle se bliží, nicméně, aby to všechno do sebe zapadalo, čekalo mě ještě spousta práce od studentské tvorby ke skutečné architektuře a od $3 \mathrm{D}$ modelování $\mathrm{k}$ opravdovému BIM.

Ve druhé polovině roku 2018 (po 4 letech), nadešel ten správný čas - byly splněny všechny předpoklady, pro účely implementace $v$ mé vlastní projekční kanceláři jsem začala testovat první vlaštovky pro využití brýlí 
v projekční praxi. A já jsem si konečně mohla poprvé vyzkoušet jaké to je procházet se digitálním modelem stavby ve virtuální realitě. Jednalo se o brýle HTC. 1080 × 1200px, celkem 2160 × 1200 px .

Vypadají úchvatně oproti těm přechozím. Bohužel realita byla taková, že byly velice těžké. No a jaký byl dojem? Snažila jsem se Vám nasimulovat, jak ten obraz asi v těch brýlích vypadal. (Obr.1) Pro mě to bylo docela zklamání. Nepoužitelné na cokoli.

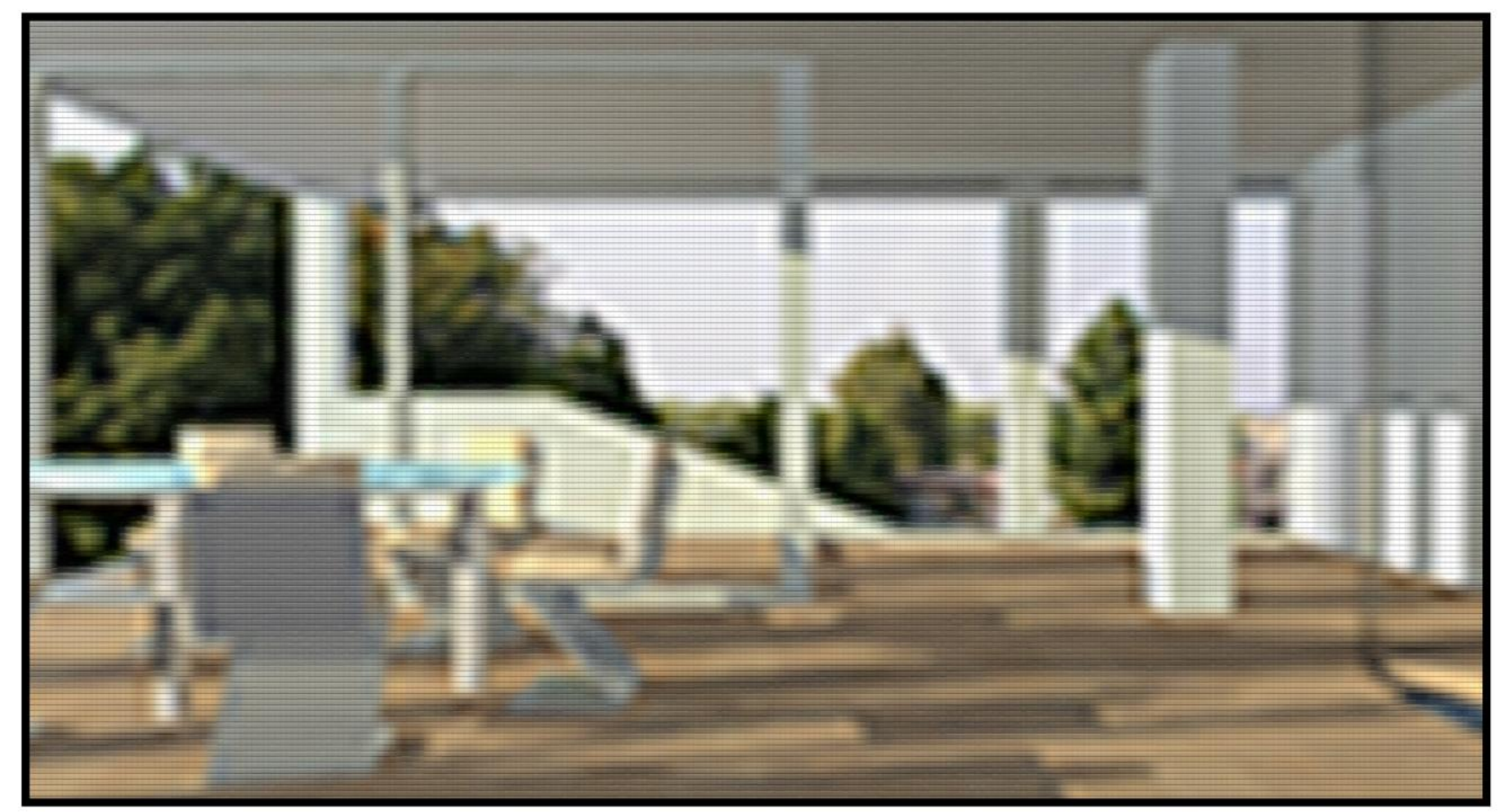

Obr. 1 simulace vnímání virtuální reality v brýlích HTC 1080 × 1200px, celkem 2160 × 1200 px

Asi o půl roku později jsem testovala brýle pro pasivní VR v mobilu. Jednalo se o model Oculus, obraz byl již lepší, nicméně pasivní virtuální realita nenaplňovala naše potřeby volné vizuální kontroly modelu.

Nová generace brýlí pro aktivní Virtuální realitu na jaře 2019 již byla z hlediska obrazu uspokojivá. 2× $1440 \times$ 1600 px celkem $2880 \times 1600$ px HTC Vive Pro. Začalo tedy intenzivní hledání jaký hardware, software a metodika přinese kýžené řešení. Neexistoval jednoznačný návod. Všechno souviselo se vším.

V létě roku 2019 jsme objevili brýle HP Reverb Professional - rozlišení 4K (2160x2160px celkem4320x2160px) v roce 2019 a donedávna stále nejlepší dostupné na trhu. Studovali jsme různé recenze, pročítali články a čekali jsme do ř́jna než se brýle dostaly na trh a my si je mohli objednat. A s výsledkem jsme byli spokojení.

Ačkoli v brýlích nevidíme tak ostře jako ve skutečnosti, (obr. 2) je míra detailu dostatečná, abychom vnímali detaily o velikosti $5 \mathrm{~mm}$, jak ukázalo naše testování. Takže pokud zvažujete nákup brýlí pro VR, určitě neinvestujte do brýlí o menším rozlišení.

Tyto brýle nyní používáme nyní $s$ úspěchem $v$ naší kanceláři. Aktuálně HP má $k$ prodeji připravený nový model HP Reverb G2 o stejném rozlišení $4 \mathrm{~K}$ ale s vylepšeným trackingem. Toto zařízení jsme ale zatím neměli možnost otestovat. 


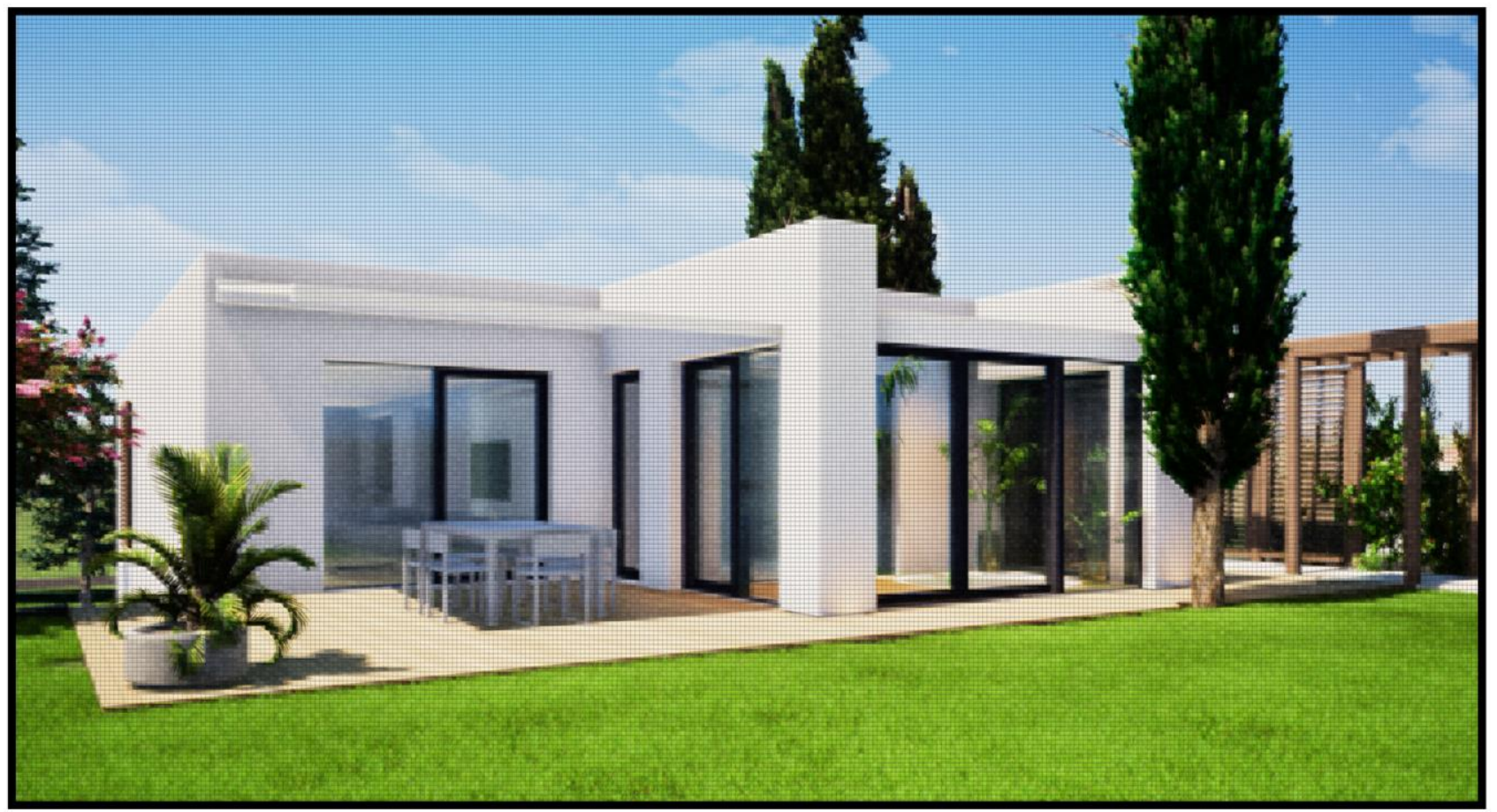

Obr. 2 simulace vnímání virtuální reality v brýlích HP Reverb Professional - rozlišení 4K (2160x2160px celkem4320x2160px)

No a pokud byste chtěli mít v současnosti ve virtuální realitě skutečně obraz bez všech kompromisů, tak musíte si ještě nějakých 180000 Kč připlatit a sáhnout po headsetu od VRgineers XTAL, který je v současnosti nejlepším komerčně dostupným headsetem s rozlišením $4 \mathrm{~K}$ na jediné oko, tedy $8 \mathrm{~K}$ a zorným polem $180^{\circ}$. (Obr. 3)

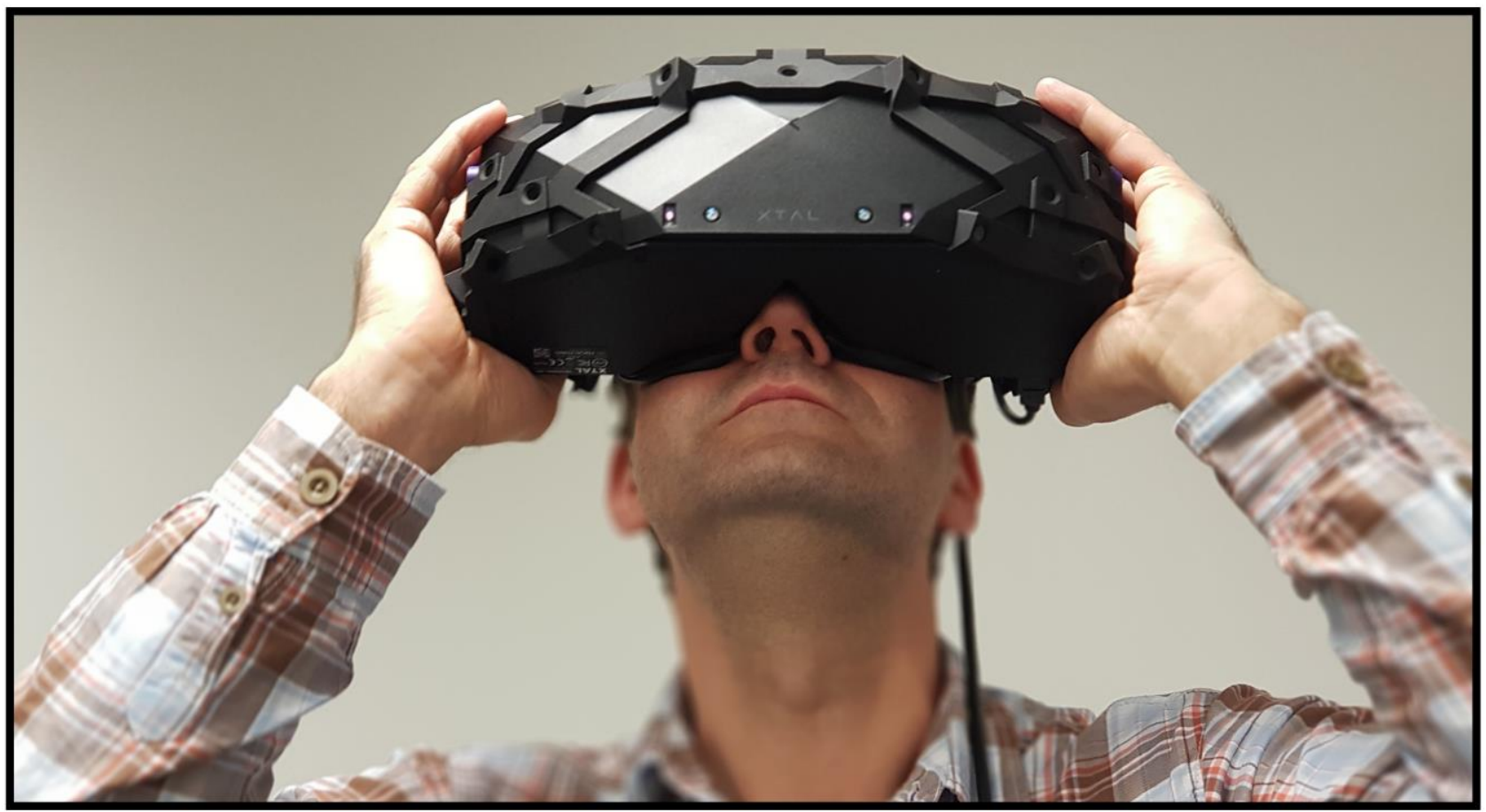

Obr. 3 brýle XTAL od VRgineers při testování v kanceláři Ateliér Ostrava s.r.o. 
V současnosti používáme $v$ kanceláři na stanici pro VR tento HW:

grafická karta: NVIDIA GEFORCE RTX 2080 SUPER

procesor: Intel Core i7-9700

pamět: 32GB RAM HyperX FURY DDR4 32GB (Kit 2x16GB) 2666MHz CL16 černá

disk: SSD 500GB - Samsung SSD 970 EVO PLUS 500GB MZ-V7S500BW

A jaké máme aktuálně softwarové možnosti pro VR? Protože výběr softwaru úzce souvisí $s$ metodikou, podíváme se na jednotlivé programy $v$ další sekci.

\section{SPECIFIKA WORKFLOW V NÁVAZNOSTI NA BIM}

Napřed se podívejme, jak vypadá navázání BIM na VR v prostředí 3DS Max z rodiny Autodesk. (Obr.4) Nevýhodou tohoto postupu je osoba vizualizátora, která do modelu zasahuje. Ztrácí se tak př́má a okamžitá návaznost BIM na VR.

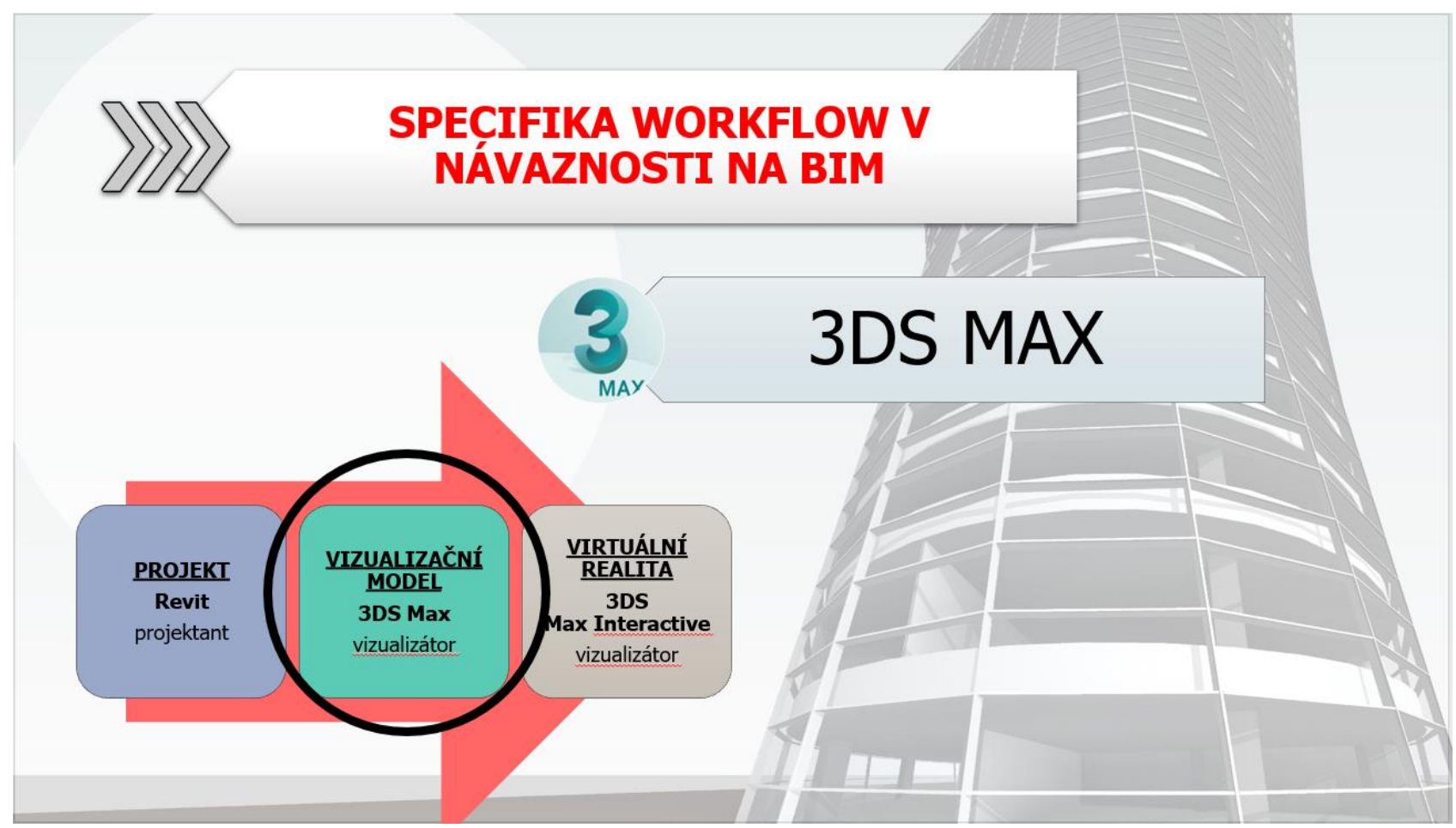

Obr. 4 schéma navázání VR na BIM v prostředí řešení Autodesk

V současnosti nejpropagovanější alternativou pro virtuální realitu $v$ BIM je Enscape. Zde naopak vše co vidíte $v$ BIM modelu se zároveň zobrazuje $v$ modelu ve VR. (Obr. 5) Toto řešení jsme testovali podrobněji, ale nevyhovovalo nám z několika důvodů. Zejména správu materiálů provádíte prímo $v$ software pro BIM v našem př́padě Revit. Správa materiálů do vizualizační kvality je něco, co po stavebním projektantovi nemůžete chtít. Zároveň do vizualizací potřebujete umístit i prvky jako zeleň stafáž aj., které do BIM modelu nepatří. Jak toto vyřešit? 


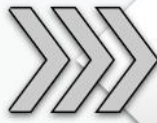

\section{SPECIFIKA WORKFLOW V NÁVAZNOSTI NA BIM}

\section{PROJEKT \\ VIRTUÁLNÍ \\ Revit \\ projektant \\ REALITA \\ Enscape \\ projektant}

\section{ENSCAPE}

Obr. 5 schéma navázání VR na BIM v softwaru Enscape

My jsme se rozhodli ve své době pro úplnou novinku program Twinmotion. (Obr. 6) Proč? Protože právě řeší všechny problémy, kde jsme $\mathrm{s}$ předchozími programy narazili. Je zde př́má návaznost na BIM model. Přechod do virtuální reality zvládne projektant po jednodenním zaškolení, zároveň však $v$ případě potřeby na pokročilé vizualizace je možné do procesu začlenit i zkušeného vizualizátora a doplnit stafáž, zeleň, a pokročilé mapování materiálů.

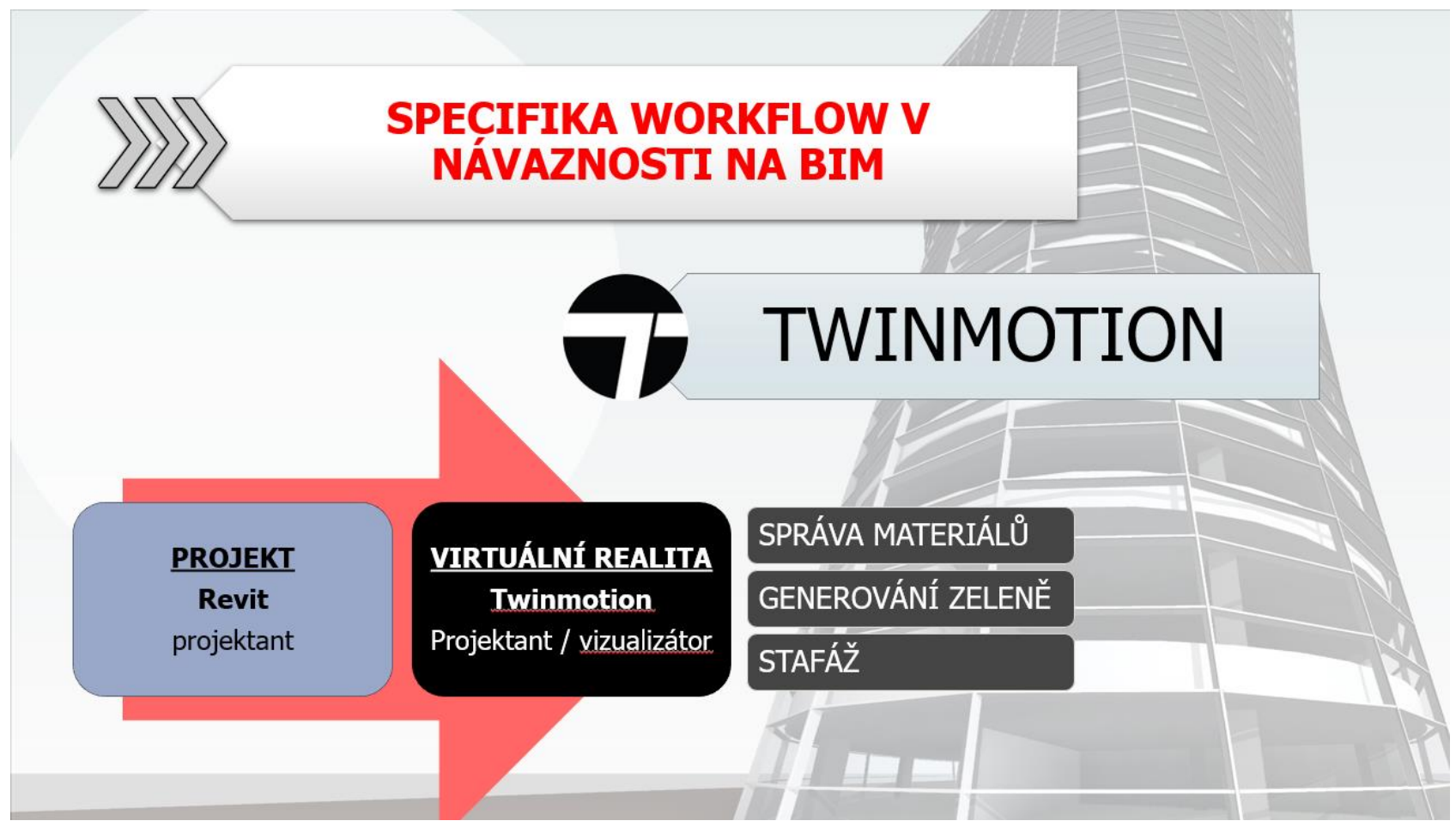

Obr. 6 schéma navázání VR na BIM v softwaru Twinmotion 
Podíváme-li se na problematiku propojení VR a BIM podrobněji, jedním z prvních problémů, který budete řešit, bude volba přístup ke konstrukcím, které jsou sice pohledově viditelné, ale standardně se nemodelují. Ukážeme si to na příkladu stěny z plných cihel v projektu pasportizace. (Obr.7) Naší podmínkou bylo že úpravy pro VR na hlavním BIM modelu objektu musí být v souladu se všemi ostatními požadavky na BIM a nesmějí hodnotu BIM modelu v žádném směru degradovat. Tzn. samoúčelné dosažení vzhledu bez návaznosti na správnou rodinu, kategorii, informace, vykazování, popisku, zobrazení je nepř́ípustné!

Vyřešili jsme to způsobem, kdy jsme požadovaný vzhled povrchu spojili s daným konstrukčním materiálem, který jsme označili textovou poznámkou o charakteru povrchu.

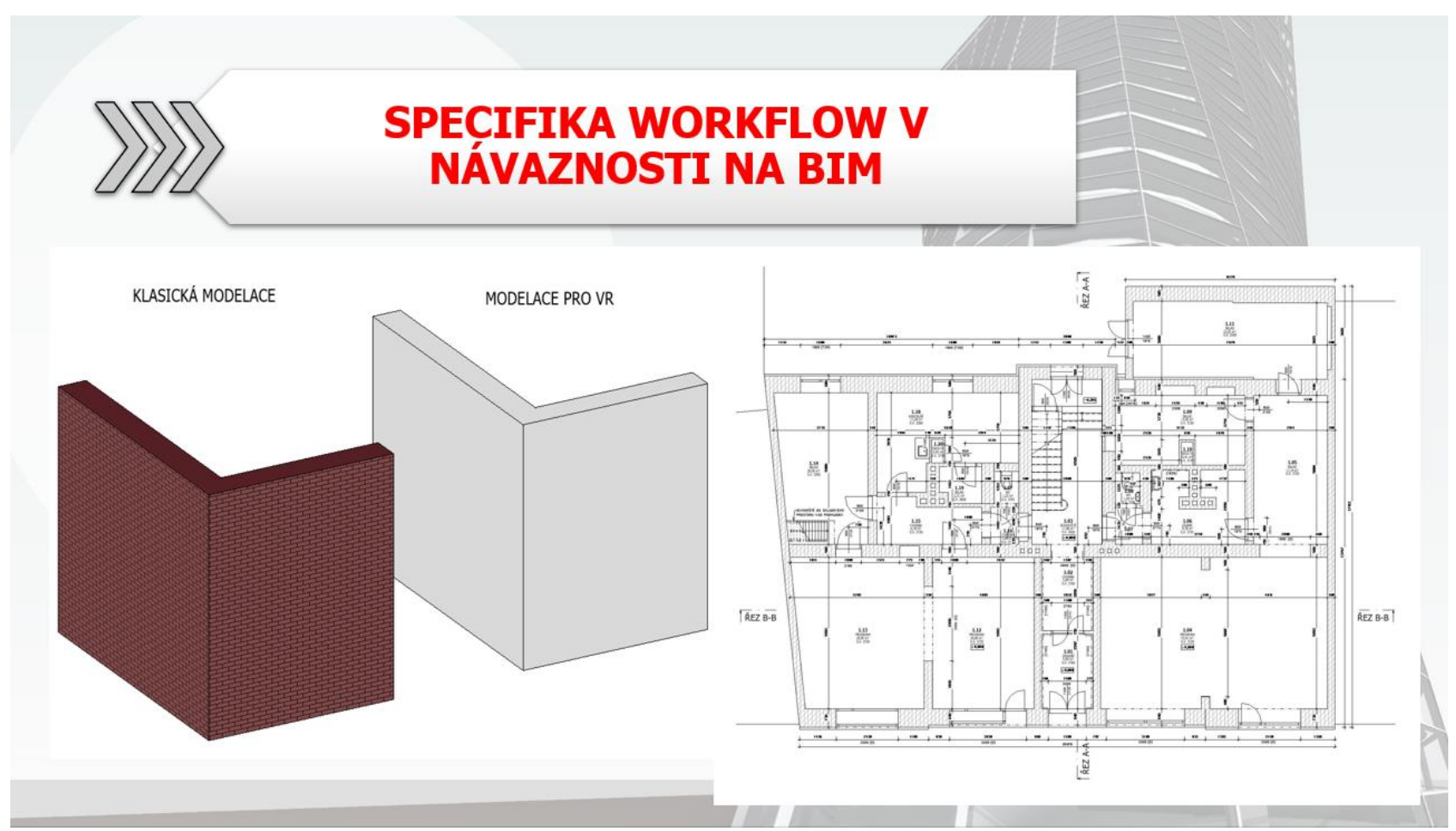

Obr. 7 modelace konstrukcí s ohledem na vzhled jejich povrchu

\section{UKÁZKY VYBRANÝCH PROJEKTU゚}

Virtuální realitu využíváme u projektů ve všech projekčních fázích - od konceptu, studie (Obr.8), až po dokumentaci pro provádění stavby. Výhodou je zejména neuvěřitelná kvalita komunikace s klientem, kdy má veškeré podklady pro rozhodování dostupné tou nejpřijatelnější formou a dokáže si reálnou situaci po výstavbě představit - doslova ji vidí na vlastní oči. Není nutné hodiny studovat výkresy, ale stačí si projít model, ze kterého jsou výkresy generovány, a zjistit i souvislosti, které se z výkresů nedají vyčíst. Exportní soubor navíc umožňuje bez další instalace zobrazovat virtuální realitu i kdekoli jinde na světě, postačující je PC s kvalitní grafickou kartou a vlastní headset. Nebo jen využít procházení modelu na obrazovce monitoru. Virtuální realita je tím nejkvalitnějším a zároveň nejpříjemnějším způsobem pravidelní komunikace všech vizuálně reprezentovatelných dat BIM modelu, a to v reálné praxi. 


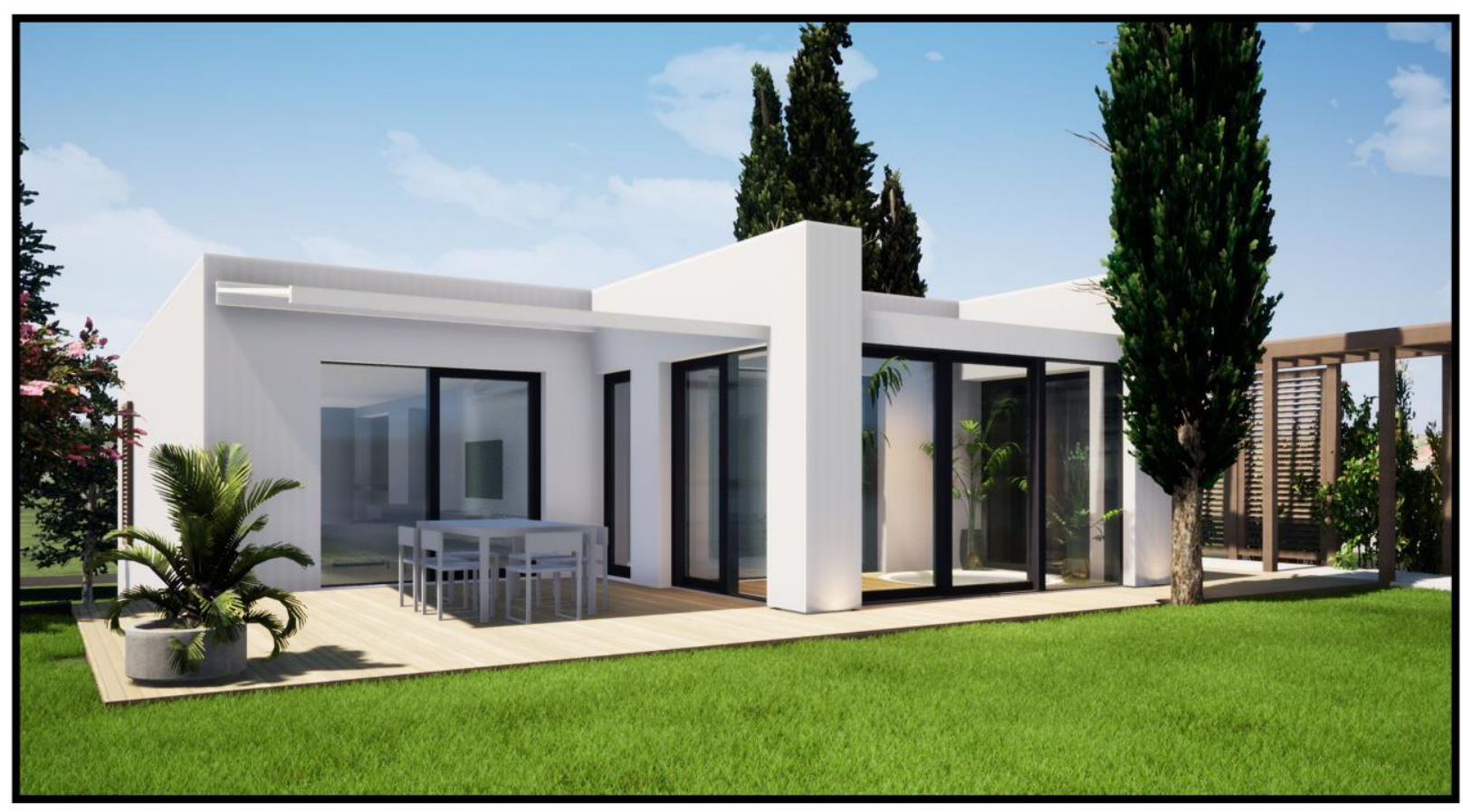

Obr. 8 vizualizace modelu BIM z virtuální reality ve fázi studie bez jakékoli postprodukce

Odkaz na video z virtuální reality ve fázi studie: https://youtu.be/yy Z-sY8vNk 